\title{
Impact of organic and inorganic fertilizers on tomato vigor, yield and fruit composition under tropical andosol soil conditions
}

\author{
Libert Brice TONFACK ${ }^{1,2}$, Anne BernadAC ${ }^{2}$, Emmanuel YoumBI ${ }^{1 *}$, V. Paul MBOUAPOUOGNIGNI ${ }^{3}$, Martin NGUeGUim ${ }^{3}$, Amougou AKOA $^{1}$
}

${ }^{1}$ Lab. Biotechnol. Environ. Dep. Plant Biol., Fac. Sci., Univ. Yaoundé 1, Cameroon youmbi_emmanuel@yahoo.fr

2 Lab. Genomics Fruit Biotechnol., UMR 990, INRA INP-ENSAT, Toulouse, France

${ }^{3}$ Dep. Hortic. Plant, Inst. Agric. Res. Dev. (IRAD), Foumbot, Cameroon

* Correspondence and reprints

Received 5 August 2008 Accepted 5 December 2008

Fruits, 2009, vol. 64, p. 167-177 (C) 2009 Cirad/EDP Sciences All rights reserved DOI: 10.1051/fruits/2009012 www.fruits-journal.org

RESUMEN ESPAÑOL, p. 177
Impact of organic and inorganic fertilizers on tomato vigor, yield and fruit composition under tropical andosol soil conditions.

Abstract - Introduction. Little is known about the impact of organic manure on andosol. Materials and methods. Two varieties of Solanum lycopersicum L. (cvs. 'Rio grande' and 'Rossol VFN') were grown under tropical andosol. The soil was silty, acidic and very poor in Bray $\mathrm{P}\left(3 \mathrm{mg} \cdot \mathrm{kg}^{-1}\right)$ with a strong imbalance in the $(\mathrm{Ca}: \mathrm{Mg}: \mathrm{K})$ ratio of $(74.0: 25.0: 0.7)$. Five fertilization treatments were used: (i) control with no fertilizer, (ii) minerals, with a (Ca:Mg:K) ratio of (76:18:6) and $75 \mathrm{mg} \mathrm{P} \cdot \mathrm{kg}^{-1}$ of soil; (iii) poultry manure with a (Ca:Mg:K) ratio of $(68: 24: 7)$ and $450 \mathrm{mg} \mathrm{P} \cdot \mathrm{kg}^{-1}$ of soil; (iv) a combination of (ii) and (iii), and (v) mineral fertilization as applied by local farmers, with a (Ca:Mg:K) ratio of $(73: 25: 1)$ and $54 \mathrm{mg} \mathrm{P} \cdot \mathrm{kg}^{-1}$ of soil. Results. All cationbalanced treatments (organic, mineral or a combination of both) significantly improved plant growth, the number of trusses and fruits per plant, the marketable fruit yield and fruit $\mathrm{P}, \mathrm{K}, \mathrm{Ca}$ and $\mathrm{Na}$ contents of both tomato varieties considered. The 'Rio grande' variety was the most productive (32-44 th ha ${ }^{-1}$ ) compared with the 'Rossol' variety $\left(20-22 \mathrm{t} \cdot \mathrm{ha}^{-1}\right)$. There was no major difference between the organic fertilizer and the cation-balanced mineral fertilizer. There was no effect of mineral fertilizer with an unbalanced cation composition on tomato plant growth and production as compared with unfertilized control. Conclusion. In tropical andosol poor in potassium and phosphorous and with excess of $\mathrm{Mg}$, application of poultry manure in adequate dosage and at the right time is capable of sustaining tomato fruit production, as well as the application of calculated inorganic fertilizer.

Cameroon / Solanum lycopersicum / fruits / andosols / fertilizer application / inorganic fertilizers / organic fertilizers / growth / quality

Impact des engrais organiques et inorganiques sur la vigueur, le rendement et la composition du fruit de tomates cultivées sur des andosols tropicaux.

Résumé - Introduction. Il existe peu d'informations sur l'impact des engrais organiques sur les andosols. Matériel et méthodes. Deux variétés de tomate (Solanum lycopersicum L.), cv. 'Rio grande' et 'Rossol VFN', ont été cultivées sur andosols tropicaux. Le sol était limoneux, acide, très pauvre en phosphore Bray $\left(3 \mathrm{mg} \cdot \mathrm{kg}^{-1} \mathrm{de} \mathrm{sol}\right)$ avec un fort déséquilibre du rapport $(\mathrm{Ca}: \mathrm{Mg}: \mathrm{K})$ égal à (74.0:25.0:0.7). Cinq traitements de fertilisation ont été testés : (i) traitement témoin sans engrais, (ii) engrais minéral équilibré en cations [(rapport (Ca:Mg:K) = (76:18:6) et $75 \mathrm{mg} \mathrm{P} \cdot \mathrm{kg}^{-1} \mathrm{de} \mathrm{sol]} \mathrm{;} \mathrm{(iii)} \mathrm{fumier} \mathrm{de} \mathrm{volaille} \mathrm{avec} \mathrm{un} \mathrm{rapport} \mathrm{(Ca:Mg:K)} \mathrm{de}(68: 24: 7)$ et $450 \mathrm{mg}$ $\mathrm{P} \cdot \mathrm{kg}^{-1}$ de sol ; (iv) combinaison des traitements (ii) et (iii); (v) fertilisation minérale déséquilibrée en cations, telle qu'appliquée par les agriculteurs locaux [rapport $(\mathrm{Ca}: \mathrm{Mg}: \mathrm{K})=(73: 25: 1)$ et $54 \mathrm{mg} \mathrm{P} \cdot \mathrm{kg}^{-1}$ de sol]. Résultats. Les fertilisations équilibrées en cations (organique, minérale ou organo-minérale) ont sensiblement amélioré la croissance des plantes, le nombre de grappes et de fruits par plante, le rendement en fruits commercialisables et la teneur en $\mathrm{P}, \mathrm{K}$, Ca et $\mathrm{Na}$ des deux variétés de tomate considérées. La variété 'Rio Grande' a été plus productive (32$44 \mathrm{t} \cdot \mathrm{ha}^{-1}$ ) que la variété 'Rossol' $\left(20-22 \mathrm{t} \cdot \mathrm{ha}^{-1}\right)$. Il n'y a pas eu de différences majeures entre les plants fertilisés avec l'engrais organique et ceux ayant reçu un engrais minéral équilibré en cations. La fertilisation minérale déséquilibrée en cations n’a pas eu d'effet sur la croissance et la production des plants de tomate par rapport au traitement témoin sans engrais. Conclusion. Dans les andosols tropicaux pauvres en potassium et en phosphore et présentant un excès de magnésium, l'application de fumier de volaille à des doses adaptées et au bon moment permet de maintenir une production de tomates équivalente à celle obtenue avec un engrais minéral bien dosé.

Cameroun / Solanum lycopersicum / fruits / andosol / fertilisation / engrais minéral / engrais organique / croissance / qualité 


\section{Introduction}

Agriculture in tropical Africa is strongly limited by numerous constraints. Most soils in Africa are poor compared with other parts of the world [1]. African soil nutrient balances are often negative due to a low level of fertilizer inputs, and soil nutrient depletion is a major reason for decreasing or stagnation of agricultural productivity [2]. Moreover, African soils are classified by the Food and Agriculture Organization (FAO) as greatly diversified and therefore, it is difficult to make a general recommendation for agricultural practices.

In Cameroon, the western highlands are classified by the World Reference Base (WRB) for soil resources system as dominantly covered by andosol ${ }^{1}$. This region is one of the main agricultural areas in Central Africa and this zone is considered to have a medium to high agricultural potential [1]. Soils are widely cropped [3] and the fruit and vegetable market has been one of the main innovations of the farmers, following the coffee crisis in the 1990s [4]. In this region, andosols are characterized by their high content of organic matter and their good capacity for water retention and are the most solicited soils for tomato culture. However, traditional agriculture practices result in mining soils of plant nutrients by leaching, soil erosion and removal of crop residues [5], leading to decreased fertility. Moreover, there is a lack of experimentation and communication on soil fertility management Consequently, as reported in other regions in Africa, local farmers use in a very costly manner inadequate nutrient inputs, inappropriate quality and inefficient combinations of fertilizers [6]. This situation drives inexorably to a deeply unbalanced soil nutrient composition, leading to a decrease in crop yield potential. Tomato culture in the western highlands of Cameroon produces very weak outputs, although the producers use significant quantities of fertilizers. This fertilization mostly consists of inorganic compounds. Little is known about the

${ }^{1} \mathrm{FAO} / \mathrm{AGL}$ (Food and Agriculture Organization), World reference base for soil resources, http://www.fao.org/ag/agl/agll/ wrb/mapindex.stm, 2003. impact of organic manure on andosol [7], and the mineralization of organic matter in andosol and subsequent solute transfers involve complex mechanisms [8]. Nevertheless, it is known that, in andosol, organic compounds counteract ion phosphate adsorption by blocking their adsorption sites [9] on crystallized oxides of $\mathrm{Fe}$ or $\mathrm{Al}$ and make them more available for the plant.

The aim of our experiment was to investigate alternative methods of fertilization for tomato production on andosol in the western highlands of Cameroon:

(i) with the introduction of organic fertilization using a locally produced poultry manure,

(ii) taking into account the soil analysis and the culture nutrient requirement to calculate the fertilization input.

\section{Materials and methods}

\subsection{Culture conditions and experimental design}

An open field experiment with two tomato plant varieties (Solanum lycopersicum L., cvs. 'Rio grande' and 'Rossol VFN') was carried out at the garden of the Institute of Agricultural Research for Development of Foumbot (long. 10 $27^{\prime}-10^{\circ} 47^{\prime} \mathrm{E}$, lat. $5^{\circ} 14^{\prime}-$ $5^{\circ} 48^{\prime} \mathrm{N}$, alt. $1100 \mathrm{~m}$ ) in the western highlands of Cameroon, from September 2005 to January 2006. The two tomato varieties are supposed to be equally adapted to the tropical area conditions, with a medium harvest homogeneity and potential yield of 50 $60 \mathrm{t} \cdot \mathrm{ha}^{-1}$.

Seeds of tomato produced by Technisem (Savigny-sur-Orge, France) were sown on September 21, 2005. Forty-day-old seedlings were transplanted into $6-\mathrm{m}^{2}$ plots. On each experimental plot, seedlings were transplanted in three rows (four plants per row) at $1.0-\mathrm{m}$ distance between rows and $0.5-\mathrm{m}$ distance within rows. The experimental design was a split-plot with the two varieties as main plots, divided by five different nutrient treatments. Each treatment had four replicates. Climatic conditions prevailing during the experimental period were registered 
Table I.

Climatic conditions prevailing in the experimental field, during the experiment (Foumbot, western highlands of Cameroon).

\begin{tabular}{cccccc} 
Year & Month & $\begin{array}{c}\text { Total precipitations } \\
(\mathrm{mm})\end{array}$ & \multicolumn{2}{c}{ Temperature $\left({ }^{\circ} \mathrm{C}\right)$} & Total sunlight \\
\hline 2005 & September & 292.5 & 15.0 & 27.0 & 119.4 \\
& October & 316.5 & 15.0 & 27.2 & 98.6 \\
& November & 6.7 & 14.1 & 30.9 & 121.0 \\
& December & 0 & 12.3 & 30.1 & 195.0 \\
2006 & January & 46.0 & 14.8 & 29.6 & 188.0
\end{tabular}

Source: Meteorology section, Inst. Agron. Res. Dev. Foumbot, Cameroon, 2006.

(table I). During September and October 2005, plants received water only from rain. From November 2005 to January 2006, plots received water by capillary rise of water from irrigation. Plants were treated twice against insects and fungi with endosulfan and mancozeb.

\subsection{Soil and manure analysis}

In order to elaborate fertilization plans, soil and manure were analyzed. The andosol soil sample was collected at $15-\mathrm{cm}$ depth at five different places all over the $1000-\mathrm{m}^{2}$ experimental garden, mixed and analyzed for texture and chemical characteristics. Soils were air-dried and ground to pass through a $2-\mathrm{mm}$ sieve. Soil $\mathrm{pH}$ in water was determined in a 1:2.5 (w/v) soil:water suspension. Organic $\mathrm{C}$ was determined by chromic acid digestion and spectrophotometric analysis [10]. Total $\mathrm{N}$ was determined from a wet acid digest [11] and analyzed by colorimetric analysis [12]. Exchangeable $\mathrm{Ca}$, $\mathrm{Mg}, \mathrm{K}$ and Na were extracted using the Mehlich procedure and determined by atomic absorption spectrophotometry. Available P was extracted by the Bray-1 procedure and analyzed using the molybdate blue procedure described by Murphy and Riley [13].

Poultry manure was collected from a local farmer and analyzed for chemical characteristics as follows: cations ( $\mathrm{Ca}, \mathrm{Mg}$ and $\mathrm{K}$ ) were determined by dry ashing in a muffle furnace at $500{ }^{\circ} \mathrm{C}$, diluted using aqua regia (acid mix of $\mathrm{HCl} / \mathrm{HNO}_{3}$ ) and analyzed using an atomic absorption spectrophotometer.
Phosphorus was extracted by dry ashing and analyzed by colorimetry [13]. Data are reported as a percentage of dry matter. Total $\mathrm{N}$ was determined from a wet acid digest [11] by colorimetric analysis [12].

\subsection{Fertilization treatments}

Five different treatments were applied:

- F0: control without any nutrient supply;

- F1: potassium sulfate $\left(50 \% \mathrm{~K}_{2} \mathrm{O}\right)$, calcium nitrate $(15.5 \% \mathrm{~N}+26.5 \% \mathrm{CaO})$, triple superphosphate $\left(46 \% \mathrm{P}_{2} \mathrm{O}_{5}+20 \% \mathrm{CaO}\right)$ and NPK $\left(14 \% \mathrm{~N}+5 \% \mathrm{P}_{2} \mathrm{O}_{5}+18 \% \mathrm{~K}_{2} \mathrm{O}\right)+\mathrm{Mg}$ ( $4 \% \mathrm{MgO}$ ). These different mineral formulations were used to provide $188 \mathrm{~kg} \mathrm{~N} \cdot \mathrm{ha}^{-1}$, $80.2 \mathrm{~kg} \mathrm{P} \mathrm{P}_{2} \mathrm{O}_{5} \cdot \mathrm{ha}^{-1}, 402.5 \mathrm{~kg} \mathrm{~K}_{2} \mathrm{O} \cdot \mathrm{ha}^{-1}, 250 \mathrm{~kg}$ $\mathrm{CaO} \cdot \mathrm{ha}^{-1}$ and $32 \mathrm{~kg} \mathrm{MgO} \cdot \mathrm{ha}^{-1}$, to respect the tomato plants' demand for a maximal fruit output of $50-60 \mathrm{t} \cdot \mathrm{ha}^{-1}$ [14]. This contributed to having a soil final cation balance [Ca:Mg:K] ratio of [75.2:18.0:5.8]. The fertilization was done in three applications: $50 \% \mathrm{~N}, 80 \% \mathrm{~K}_{2} \mathrm{O}, 100 \% \mathrm{P}_{2} \mathrm{O}_{5}, 100 \% \mathrm{MgO}$ and $84 \% \mathrm{CaO}$ were applied 1 week before transplantation; then $25 \% \mathrm{~N}, 10 \% \mathrm{~K}_{2} \mathrm{O}$ and 8\% CaO were applied (2 and 4) weeks after transplantation;

- F2: poultry manure was applied 2 weeks before transplantation at $20 \mathrm{t} \cdot \mathrm{ha}^{-1}$ and completely mixed with soil, contributing to a balanced [Ca:Mg:K] ratio of [68:24:7];

- F3: organo-mineral treatment consisted of the mixture of inorganic fertilizer (F1) and poultry manure (F2) on the same plots; 

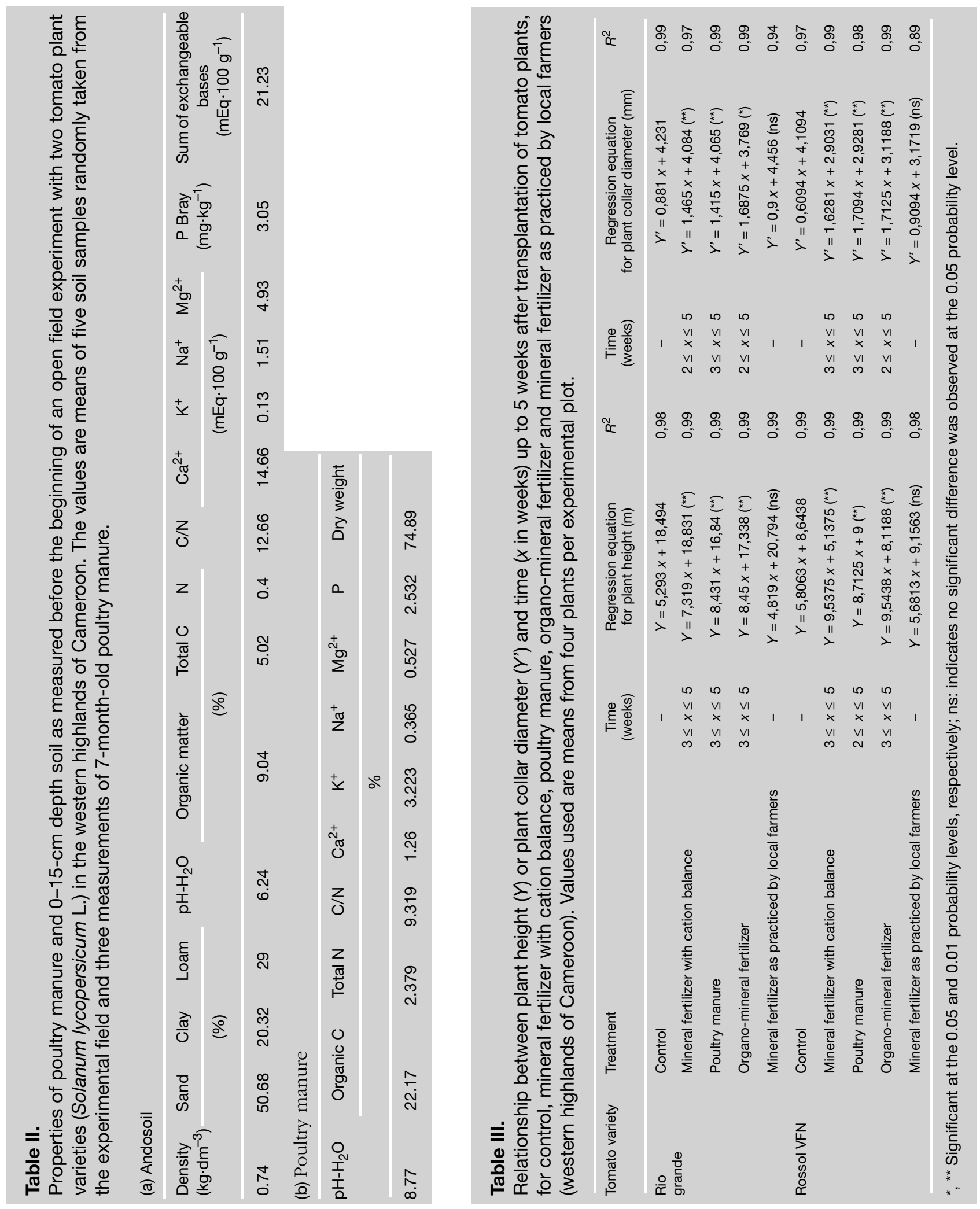
- F4: $600 \mathrm{~kg}$ of mineral fertilizer [N:P:K] [20:10:10] per ha was applied 1 week after transplantation and completed 3 weeks later with urea $(50 \% \mathrm{~N})$ at $100 \mathrm{~kg} \cdot \mathrm{ha}^{-1}$ as practiced by local farmers.

\subsection{Evaluation of plant growth, development and yield}

The stem collar diameter $(2-3 \mathrm{~cm}$ above the soil surface) and plant height (from the soil up to the apex) were measured and the number of leaves was counted at 7-day intervals, beginning at the transplanting date up to 5 weeks after transplantation. The number of trusses per plant was counted at 72 days after transplantation. Tomato fruits were harvested at the orange to red stage for yield determination. The number and fresh weight of marketable fruits per plant were determined and yield was estimated in t. ha ${ }^{-1}$.

\subsection{Fruit sampling and mineral analysis}

Sampling took place regularly on a daily basis and was performed randomly from the third trusses of four plants. Fruits were tagged at setting, when the fruit was apparent. Tagged fruits were collected for mineral analysis at 55-60 days after setting (red ripe) and transported to the laboratory in refrigerated containers. Two fruits per experimental plot were collected on two different plants, with $n=3$. The six fruits were used to determine fresh weight, then three of them were oven-dried at $65^{\circ} \mathrm{C}$ until constant weight. The dry samples were homogenized and used for the determination of macronutrient ( $\mathrm{N}, \mathrm{P}, \mathrm{K}, \mathrm{Ca}, \mathrm{Mg}$ and $\mathrm{Na}$ ) contents.

Total nitrogen was obtained by the Dumas method, while other nutrients were measured after dry ashing at $550{ }^{\circ} \mathrm{C}$ by colorimetry for $\mathrm{P}$ and by flame emission $(\mathrm{K}$ and $\mathrm{Na}$ ) or atomic absorption ( $\mathrm{Ca}$ and $\mathrm{Mg}$ ) spectrophotometry.

\subsection{Statistical analysis of the data}

Data for vegetative growth were subjected to an analysis of variance and adjusted by regression analysis. Data for yield and macronutrient content $(\mathrm{N}, \mathrm{P}, \mathrm{K}, \mathrm{Mg}, \mathrm{Ca}$ and $\mathrm{Na}$ ) were subjected to a two-way ANOVA to determine significant differences between fertilization treatments and varieties, and interaction between fertilization and variety. The Student Newman-Keuls test at the $0.05 \%$ significance level was used to calculate Least Significant Differences.

\section{Results}

\subsection{Characteristics of soil and poultry manure}

The results regarding the soil analysis at the time of cultivation (table II) show that the soil was loamy sand and slightly acidic. Soil apparent density was also very low, revealing a very porous soil and high organic matter content. Regarding the organic matter and nitrogen content, the soil can be considered as fertile with a good potential for nitrogen mineralization. On the other hand, available phosphorous content was particularly low ( $3 \mathrm{mg} \mathrm{P} \cdot \mathrm{kg}^{-1}$ of soil) and the soil is also very poor in potassium ( $0.13 \mathrm{mEq} \cdot 100 \mathrm{~g}^{-1}$ of soil). The exchangeable cation values reveal that the soil was profoundly unbalanced with excess of magnesium and insufficient levels of potassium $[(\mathrm{Ca}: \mathrm{Mg}: \mathrm{K})=(74.0: 25 \cdot 0: 0.7)]$.

Poultry manure is slightly alkaline and rich in macronutrients with very high contents of cations. The ratio $[\mathrm{C}: \mathrm{N}]=9.3$ reveals high nitrogen content and a good capacity for mineralization (table II).

\subsection{Plant growth and development}

Regarding plant height and stem collar diameter, significant responses $(P<0.05)$ to fertilization were observed with the two varieties (table III). A significant increase in 'Rossol VFN' tomato plant height was observed from 2 weeks after transplantation, for poultry manure (F2) and the mixture of fertilizers (F3). For the 'Rio grande' variety, plant stem collar diameter also increased significantly $(P<0.01) 2$ weeks after transplantation on plots fertilized with 


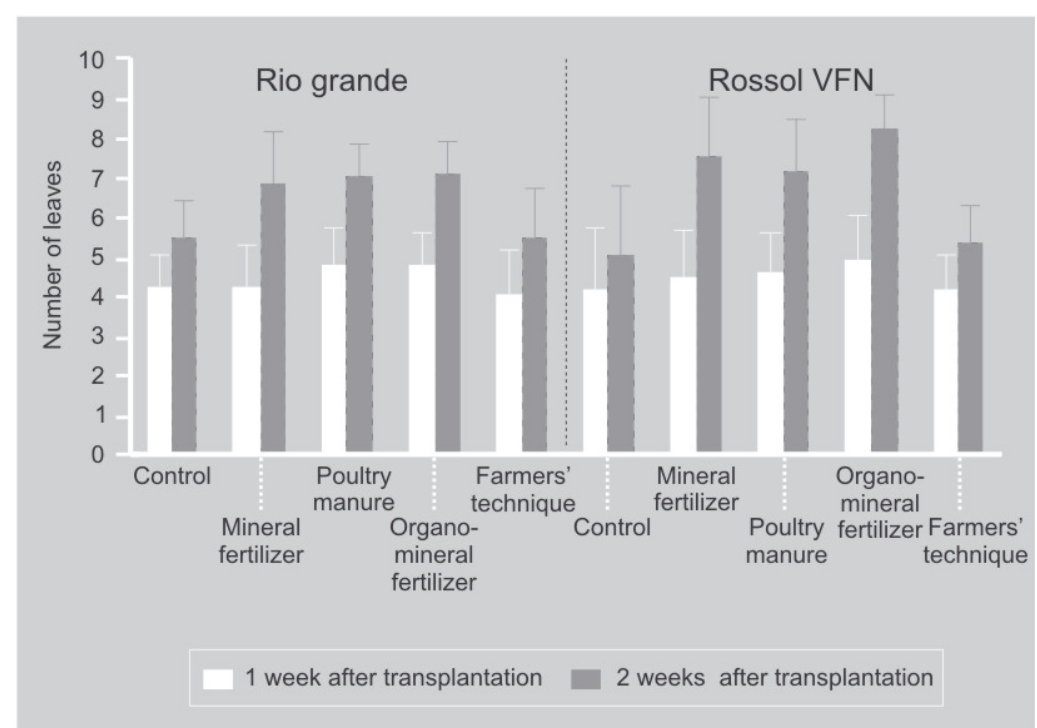

Figure 1.

Mean number of leaves counted on 'Rio grande' and 'Rossol VFN' tomato plants submitted to different fertilizer treatments (andosol soils in western highlands of Cameroon). Means with different letters are statistically different at $P<0.05$ (Student Newman-Keuls test). cation-balanced mineral fertilizer (F1), and with organo-mineral fertilizer (F3). Between (2 and 5) weeks after transplantation, the highest slopes of growth in height for 'Rio grande' (8.45) and 'Rossol VFN' (9.54) were observed with organo-mineral fertilizer. Similarly, the highest plant stem collar diameter slopes (1.7) were also observed with organo-mineral fertilizer treatment for both varieties.

Two weeks after transplantation, the number of leaves (figure 1) was significantly higher for cation-balanced mineral fertilization (F1), poultry manure (F2) and the mixture of the two fertilizers (F3) compared with the local farmers' technique (F4) and control (F0). Eight leaves were counted on tomato plants growing on plots fertilized with the mixture of fertilizers while tomato plants from plots fertilized with the local farmers' technique presented only five leaves.

\subsection{Yield}

Significant responses to fertilization and variety $(P<0.001)$ were observed for number of trusses per plant, number of fruits per plant and yield of red tomatoes (table IV). Significant responses to interaction between fertilization treatment and variety $(P<0.05)$ were observed only for the number of trusses per plant. The variety
'Rossol VFN' produced more trusses per plant (11-45), while the variety 'Rio grande' produced more fruits per plant (16-46) and the maximum yield $\left(9-44 \mathrm{t} \cdot \mathrm{ha}^{-1}\right)$. Evaluation of fruit mean weight (table IV) revealed no significant difference among the treatments.

F1, F2 and F3 treatments significantly increased $(P<0.0001)$ the number of fruits per plant by $62 \%, 100 \%$ and $123 \%$, respectively, for the variety 'Rio grande', and 143\%, $129 \%$ and $183 \%$, respectively, for the variety 'Rossol VFN', although no significant differences were observed among these treatments, as compared with control (F0). The yield of red tomatoes of both 'Rio grande' and 'Rossol VFN' was significantly higher (2 to 3 times) in plots fertilized with cation-balanced mineral fertilizer (F1), poultry manure (F2) and the mixture of the two fertilizers (F3) than in the treatment of the local farmers' technique (F4) and control (F0). 'Rio grande' tomato tended to give the maximum yield of $43.92 \mathrm{t} \cdot \mathrm{ha}^{-1}$ with the mixture of fertilizers (F3), while 'Rossol VFN' tomato tended to give the maximum yield of $22.22 \mathrm{t} \cdot \mathrm{ha}^{-1}$ on plots fertilized with mineral fertilizer with cation balance (F1). For the two varieties, there was no significant difference between the yield of tomato from the plots fertilized with the local farmers' technique (F4) and control (F0).

\subsection{Macronutrient concentrations in red fruits}

Significant responses to fertilization treatments were observed for phosphorus $(P<0.001)$, potassium $(P<0.001)$, calcium $(P<0.01)$ and sodium $(P<0.001)$ concentrations (table $V)$.

For calcium concentration, significant responses to variety $(P<0.001)$ and interaction between variety and fertilization $(P<0.01)$ were also observed. Fruits of the variety 'Rossol VFN' contained more calcium (1.9-3.1 mg $\mathrm{g}^{-1}$ dry matter) than fruits of the variety 'Rio grande' $\left(1.2-1.8 \mathrm{mg} \cdot \mathrm{g}^{-1}\right.$ dry matter). The highest calcium concentrations were observed in fruits of the variety 'Rossol VFN' fertilized with organic (3.10 mg.g-1 dry matter) and organo-mineral (2.95 mg.g ${ }^{-1}$ dry matter) fertilizers. For 


\begin{tabular}{|c|c|c|c|c|c|}
\hline Tomato variety & Treatment & $\begin{array}{c}\text { Number of trusses } \\
\text { per plant }\end{array}$ & $\begin{array}{l}\text { Number of fruits } \\
\text { per plant }\end{array}$ & $\begin{array}{l}\text { Fruit mean } \\
\text { weight }\end{array}$ & $\begin{array}{l}\text { Yield } \\
\left(\mathrm{t} \cdot \mathrm{ha}^{-1}\right)\end{array}$ \\
\hline \multirow[t]{5}{*}{ Rio grande } & Control & $9.81 \mathrm{a}$ & 16.44 a B & 46.09 & 9.38 a B \\
\hline & Mineral fertilizer with cation balance & $23.38 \mathrm{~b}$ & $33.79 \mathrm{~b}$ & 50.16 & $31.90 \mathrm{~b}$ \\
\hline & Poultry manure & $30.56 \mathrm{bc}$ & $41.67 \mathrm{~b}$ & 47.49 & $36.19 \mathrm{~b}$ \\
\hline & Organo-mineral fertilizer & $31.06 \mathrm{bc}$ & $46.35 \mathrm{~b}$ & 50.47 & $43.92 \mathrm{~b}$ \\
\hline & Mineral fertilizer as practiced by local farmers & $12.37 \mathrm{a}$ & 20.81 a & 44.82 & $13.02 \mathrm{a}$ \\
\hline \multirow[t]{5}{*}{ Rossol VFN } & Control & $11.12 \mathrm{a}$ & 6.42 a $A$ & 40.11 & 5.83 a $A$ \\
\hline & Mineral fertilizer with cation balance & $38.19 \mathrm{~cd}$ & $31.15 b$ & 39.56 & $22.22 \mathrm{~b}$ \\
\hline & Poultry manure & $43.25 d$ & $29.31 \mathrm{~b}$ & 34.73 & $19.83 \mathrm{~b}$ \\
\hline & Organo-mineral fertilizer & $45.12 \mathrm{~d}$ & $36.25 b$ & 28.77 & $21.12 b$ \\
\hline & Mineral fertilizer as practiced by local farmers & $22.44 \mathrm{~b}$ & $12.81 \mathrm{a}$ & 38.32 & $9.08 \mathrm{a}$ \\
\hline \multicolumn{2}{|l|}{ Fertilization } & 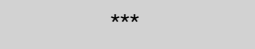 & *** & ns & 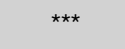 \\
\hline \multicolumn{2}{|l|}{ Variety } & *** & ** & ns & *** \\
\hline \multicolumn{2}{|c|}{ Fertilization $\times$ variety } & * & ns & ns & ns \\
\hline
\end{tabular}

the variety 'Rio grande', fruit $\mathrm{P}$ and $\mathrm{K}$ concentrations tended to be the highest with the mixture of organic and inorganic fertilizers (F3).

For the variety 'Rossol VFN', phosphorus concentration tended to be the highest with mineral fertilizer with balanced cation composition (F1) and potassium concentration tended to be the highest with the organomineral treatment (F3). Moreover, the F1 and F3 treatments induced a significant increase in sodium concentration in fruits of the variety 'Rio grande', while, for the fruits of 'Rossol VFN', no significant difference was observed with fertilization treatments. No significant responses to fertilization, variety, or interaction between fertilization and variety were observed for dry matter, nitrogen, magnesium, glucose and fructose concentrations (table V).

\section{Discussion}

The vegetative growth and the fruit productivity were improved by the three treatments
(F1), (F2) and (F3) tested, compared with the non-fertilized control (F0) and with the local farmers' technique of fertilization (F4). The two varieties were considered to be equally adapted to tropical area soils and to have the same potential yield of 50-60 th ha ${ }^{-1}$. From our experiment, it is obvious that the variety 'Rio grande' is better adapted to the local conditions, since its yield was two times greater than that of the variety 'Rossol VFN'. Globally, fruit mineral composition was similar to that mentioned in other papers [15-17] and did not show major mineral deficiencies. However, taking into account potassium, calcium and to a degree phosphorus fruit concentrations, fertilization treatments can be separated into two groups: the group of low fruit mineral concentration (with the F0 and F4 treatments) and the group of high fruit mineral concentration (with the F1, F2 and F3 treatments). Potassium nutrition was generally improved when plants were supplied with organic fertilization for the variety 'Rio grande' and with balanced mineral fertilization for the variety 'Rossol VFN'. Despite fertilization, 


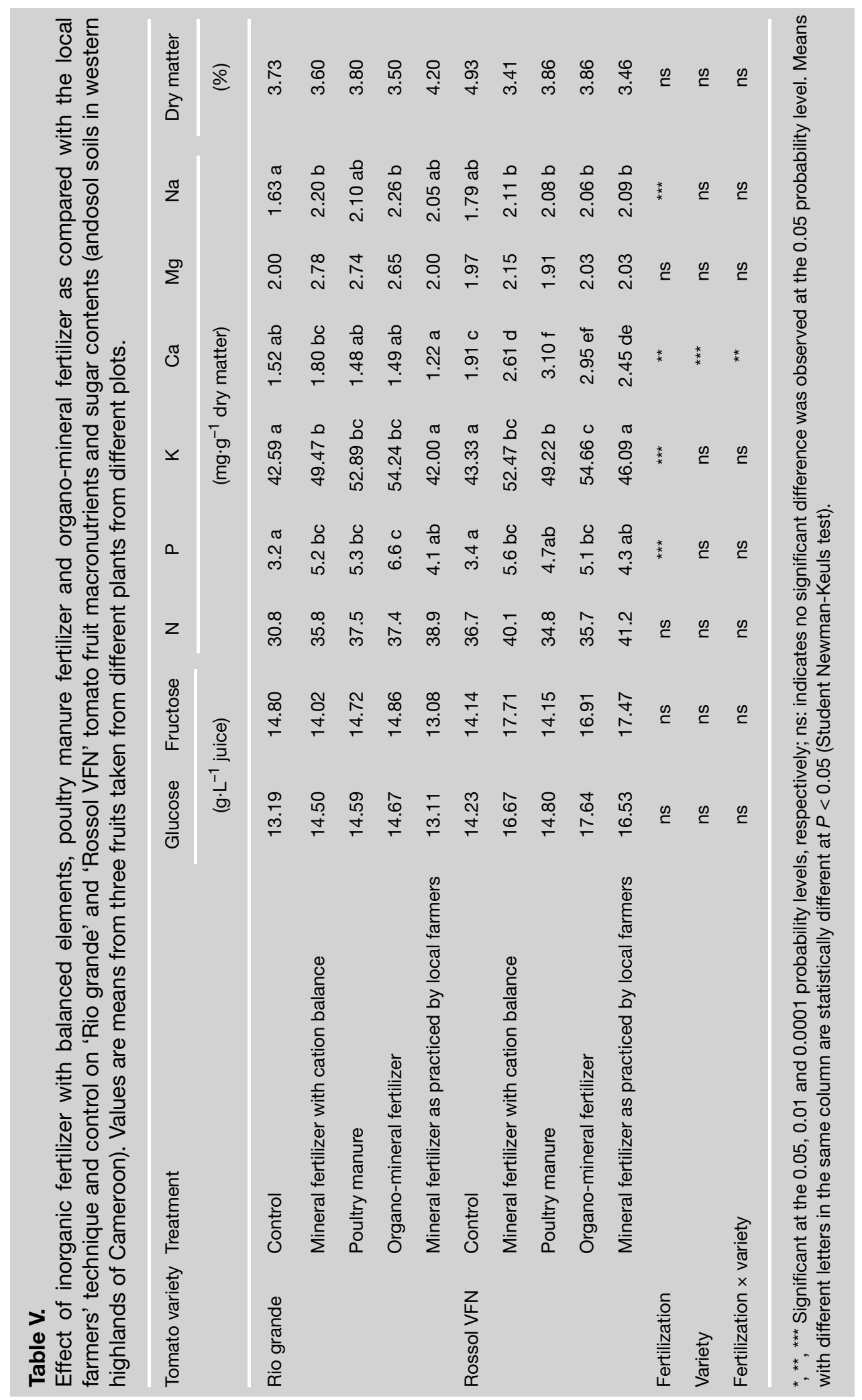


there was no significant increase in potassium concentration in the tomato fruit when the local farmers' treatment was applied. This could be explained by the relatively low amount of potassium supplied by this treatment and its imbalanced cation ratio. Potassium is known to strongly affect tomato production [16] by interfering with the uptake of Mg. Non-fertilized plots contained only $0.13 \mathrm{mEq} \mathrm{K} \mathrm{K}^{+} \cdot 100 \mathrm{~g}^{-1}$ and $3 \mathrm{mg} \cdot \mathrm{kg}^{-1}$ of phosphorus. These nutrients were probably the first limiting factor of plant growth and productivity in the (F0) treatment. Phosphorus availability in andosols is very low and this is one of the main constraints for crop production [18, 19]. Moreover, phosphorus supplied by fertilization may not be fully available, depending on the nature of the fertilizer. In our experiment, improved yields were obtained when using organic manure as compared with local fertilization. It has already been shown that phosphorus availability in andosols was improved with organic manure [20]. It is also known that the organic phosphorus fraction (75\% of total P) from poultry manure strongly integrates the pool of the soil steady organic matter [21] and organic colloids prevent soluble phosphates from linking with soluble $\mathrm{Fe}$ and $\mathrm{Al}$ in acidic soils. In fact, fulvic acids of poultry manure have significant carboxyl and hydroxyl phenolic contents that form cation complexes to a greater level and therefore increase $\mathrm{P}$ availability to plants. Improved phosphorus concentration tended to be higher with balanced mineral fertilization than with local farmers' fertilization even if the amount of applied phosphorus is very similar in the two treatments. This may be explained by the type of mineral fertilizer used, much more soluble in the balanced treatment (triple superphosphate) than in the ternary fertilizer used by local farmers.

The best outputs tended to be obtained with the treatment associating mineral fertilizer and organic fertilizer. However, yield obtained with only organic fertilization remained at a good level and, although lower, did not differ from the best output meaningfully. Poultry manure analysis indicated N, P, K, Ca and Mg contents of 2.38\%, $2.53 \%, 3.22 \%, 1.26 \%$ and $0.53 \%$, respec- tively. These values are higher than those obtained by Schmitt and Rehm [22]. Gaskell et al. found $2-3 \%$ of $\mathrm{N}$, but only $1.5 \%$ of phosphorous and potassium in chicken manure [23]. Because poultry manure is usually stored for varying lengths of time and is mixed with litter material when it is obtained from floor pens, it will vary in composition. Poultry manure induced a significant increase in 'Rossol VFN' tomato plant height at 2 weeks after transplantation while mineral fertilizer did not. These results did not corroborate those reported by Heeb et al., who estimated that limitation of nitrogen supply by organic fertilizers at the beginning of the experiment might delay plant growth, as indicated by the lower fresh weight biomass of the older plant-shoot parts [24]. In our case, there was no delay in the supply of the elements by the poultry manure. It can be assumed that over 2 weeks, poultry manure was sufficiently decomposed in this soil to enhance significant plant growth.

Our study shows that it would be possible to increase tomato production in the western highlands of Cameroon by improving the fertilization strategy. In particular, the use of poultry manure proved to be very satisfactory for the nutritional needs of the culture. These results are similar to those of Gianquinto and Borin, who found that a contribution of manure is very favorable to the high yield of industrial tomato [25]. This beneficial effect of poultry manure has been proven by other authors [26-28]. In a general way, the use of organic matter in the systems of culture should be promoted. It allows keeping soil fertility, while improving soil structure and availability of mineral elements. In fact, the increase in soil organic matter to optimum levels is a key aspect of any organic production system [23]. The locally produced poultry manure is available in good quantity and for all social groups and it seems to be economically more profitable than more expensive mineral manure. It is probable that some optimum outputs can be obtained by an organic matter contribution at the level practiced in our work and completed by a contribution of potassium mineral manure. 


\section{Conclusion}

The treatments with mineral fertilizer with cation balance (F1), with poultry manure (F2) and with organo-mineral fertilizer (F3) had a greater fruit yield than the other treatments [control without any nutrient supply (F0), and local farmers' treatment (F4)]. This means that the typical fertilization in this area (F4) is not adequate. The treatments (F1), (F2) and (F3) had similar yield (no significant differences), thus cheaper, easier to apply and sustainable the fertilizers should be the best ones to promote. In this way, organic fertilization only could be a good strategy.

\section{Acknowledgments}

The authors thank the SCAC (CameroonFrance cooperation) for financial support during fruit analysis. Special thanks to JeanClaude Pech (Professor at ENSAT, France) for his help.

\section{References}

[1] Bationo A., Hartemink A., Lungu O., Naimi M., Okoth P., Smaling E., Thiombiano L., African soils: their productivity and profitability of fertilizer use, Background papers prepared for the African fertilizer summit, Abuja, Nigeria, 2006, 25 p.

[2] Sanchez P.A., Shepherd K.D., Soule M.J., Place F.M., Buresh R.J., Izac A.-M.N., Mokwunye A.U., Kwesiga F.R., Ndiritu C.G., Woomer P.L., Soil fertility replenishment in Africa. An investment in natural resource capital, in: Buresh R.J., Sanchez P.A. Calhoun F. (Eds.), Replenishing soil fertility in Africa, Soil Sci. Soc. Am. (SSSA), spec. publ., no. 51., Madison, WI, USA, 1997.

[3] Sansoulet J., Cabidoche Y.M., Cattan P., Adsorption and transport of nitrate and potassium in an andosol under banana (Guadeloupe, French West Indies), Eur. J. Soil Sci. 58 (2007) 478-489.

[4] Kaffo C., Culture maraîchères dans les montagnes du Cameroun occidental, Cah. Agric. 14 (6) (2005) 517-524.

[5] Smaling E.M.A., Nandwa S.M., Janssen B.H., Soil fertility in Africa is at stake, in: Buresh R.J., Sanchez P.A., Calhoun F. (Eds.),
Replenishing soil fertility in Africa, Soil Sci. Soc. Am. (SSSA), Spec. publ., No. 51., Madison, WI, USA, 1997.

[6] Palm C.A., Myers R.J.K., Nandwa S.M., Combined use of organic and inorganic nutrient sources for soil fertility maintenance and replenishment, in: Buresh R.J., Sanchez P.A., Calhoun F. (Eds.), Replenishing soil fertility in Africa, Soil Sci. Soc. Am. (SSSA), Spec. publ., No. 51., Madison, WI, USA, 1997.

[7] Dahlgren R.A., Nanzyo M., Saigusa M., Volcanic soils: an overview and new perspectives, in: Oskarsson H., Arnalds O. (Eds.), Volcanic soil resources in Europe, Abstr. COST Action 622 Final Meet., Agric. Res. Inst., Rala Rep., No. 214, Iceland, Reykjavik, 2004.

[8] Shoji S., Dahlgren R., Nanzyo M., Volcanic ash soils: genesis, properties and utilization, Elsevier, Dev. Soil Sci., vol. 21, Amst., Neth., 1993, 288 p.

[9] Mora M.L., Canales J., Interactions of humic substances with allophonic compounds, Soil Sci. Plant Anal. 26 (1995) 2805-2817.

[10] Heanes D.L., Determination of organic $C$ in soils by an improved chromic acid digestion and spectrophotometric procedure, Comm. Soil Sci. Plant Anal. 15 (1984) 1191-1213.

[11] Buondonno A., Rashad A.A., Coppola E., Comparing tests for soil fertility. II. The hydrogen peroxide/sulfuric acid treatment as an alternative to the copper/selenium catalyzed digestion process for routine determination of soil nitrogen-Kjeldahl, Comm. Soil Sci. Plant Anal. 26 (1995) 1607-1619.

[12] Anderson J.M., Ingram J.S.I., Tropical soil biology and fertility: a handbook of methods, Second ed., CAB Int., Wallingford, Oxfordshire, UK, 1993, $221 \mathrm{p}$.

[13] Murphy J., Riley J.P., A modified single solution method for determination of phosphate in natural waters, Anal. Chim. Acta 27 (1962) 31-36.

[14] Caburet A., Daly P., De Bon H., Huat J., Langlais C., Lyannaz J.-P., Ryckewaert P., Les légumes: la tomate, in: Memento de l'agronome, Cirad-Gret-Minist. Aff. Étrang., Paris, France, 2002, pp. 1045-1049.

[15] Flores P., Navarro J.M., Carvajal M., Cerda A., Maitinez V., Tomato yield and quality as affected by nitrogen source and salinity, Agron. 23 (2003) 249-256.

[16] Fontes P.C.R., Sampiao R.A., Finger F.L., Fruit size, mineral composition and quality of 
trickle-irrigated tomatoes as affected by potassium rates, Pesqui. Agropecu. Bras. 35 (1) (2000) 21-25.

[17] Sanchez Conde M.P., Influencia de la presión osmótica sobre el desarrollo y composición de la planta y fruto de tomate ( $\mathrm{LyCO}$ persicon esculentum), Agrochim. 30 (1986) 219-228.

[18] Otani T., Ae N., The status of inorganic and organic phosphorous in some soils in relation to plant availability, Soil Sci. Plant Nutr. 43 (2) (1997) 419-429.

[19] Buresh R.J., Smithson P.C., Building soil phosphorus in Africa, Soil Sci. Soc. Am. J. (Spec. publ.) 51 (1997) 111-149.

[20] Odongo N.E., Hyoung-Ho K., Choi Hee-chul, Van Straaten P., McBride B.W., Romney D.L., Improving rock phosphate availability through feeding, mixing and processing with composting manure, Biores. Technol. 98 (2006) 2911-2918.

[21] Bodet J.M., Hacala S., Aubert C., Texier C., Fertiliser avec les engrais de ferme, Ed. Inst. Elév., ITAVI-ITCF-ITP, Paris, France, 2001, $104 \mathrm{p}$.

[22] Schmitt M., Rehm G., Fertilizing cropland with poultry manure, Univ. Minnesota, Ext. serv., Publ. 05881, USA, 2002, 7 p.
[23] Gaskell M., Mitcheli J., Smith R., Koike S.T., Fouche C., Soil fertility management for organic crops, Org. Veg. Prod. Calif. Ser., Publ. 7249, 2000, 5 p.

[24] Heeb A., Lundegardh B., Savage G., Ericsson T., Impact of organic and inorganic fertilizers on yield, taste and nutritional quality of tomatoes, J. Plant Nutr. Soil Sci. 169 (2006) 535-541.

[25] Gianquinto G., Borin M., Effect of organic and mineral fertilizer application and soil type on the growth and yield of processing tomatoes (Lycopersicon esculentum Mill.), Riv. Agron. 24 (4) (1990) 339-348.

[26] Oikeh S.O., Asiegbu J.E., Growth and yield responses of tomatoes to sources and rates of organic manure in ferralitic soils, Biores. Technol. 45 (1) (1993) 21-25.

[27] Zhang C.L., Zhang Y.D., Goa Z.M., Xu G.H., Wang L.Y., Zhou Q.S., Effects of combined use of inorganic and organic fertilizers on the yield and quality of tomato, J. Soil Sci. 19 (6) (1988) 276-278.

[28] Cavero J., Plant R.E., Shennam C., Friedman D.B., The effect of nitrogen source and crop rotation on the growth and yield of processing tomatoes, Nutr. Cycl. Agroecosyst. 47 (3) (1997) 271-282.

\section{Impacto de los abonos orgánicos e inorgánicos sobre el vigor, el rendimiento} y la composición del fruto de tomates cultivados en andosoles tropicales.

Resumen - Introducción. Existe poca información sobre el impacto de los abonos orgánicos en los andosoles. Material y métodos. Se cultivaron en andosoles tropicales dos variedades de tomate (Solanum lycopersicum L.), cv. 'Río grande' y 'Rossol VFN'. El suelo era turbio, ácido, muy pobre en fósforo Bray ( $3 \mathrm{mg} \cdot \mathrm{kg}^{-1}$ de suelo) con un fuerte desequilibrio de la relación (Ca:Mg:K) igual a (74.0:25.0:0.7). Se testearon cinco tratamientos de fertilización: (i) tratamiento testigo sin abono, (ii) abono mineral equilibrado en cationes [(relación (Ca:Mg:K) $=(76: 18: 6)$ y $75 \mathrm{mg} \mathrm{P} \cdot \mathrm{kg}^{-1}$ de suelo] ; (iii) estiércol de ave con una relación (Ca:Mg:K) de (68:24:7) y $450 \mathrm{mg}$ $\mathrm{P} \cdot \mathrm{kg}^{-1}$ de suelo ; (iv) combinación de los tratamientos (ii) y (iii) ; (v) fertilización mineral desequilibrada en cationes, tal y como la que aplican los agricultores locales [relación $(\mathrm{Ca}: \mathrm{Mg}: \mathrm{K})=$ (73:25:1) y $54 \mathrm{mg} \mathrm{P} \cdot \mathrm{kg}^{-1}$ de suelo]. Resultados. Las fertilizaciones equilibradas en cationes (orgánica, mineral u órgano-mineral) mejoraron sensiblemente el crecimiento de las plantas, el número de racimos y de frutos por planta, el rendimiento en frutos comercializables y el contenido en $\mathrm{P}, \mathrm{K}$, Ca y Na de las dos variedades de tomate consideradas. La variedad 'Rio Grande' fue más productiva $\left(32-44 \mathrm{t} \cdot \mathrm{ha}^{-1}\right)$ que la variedad 'Rossol' $\left(20-22 \mathrm{t} \cdot \mathrm{ha}^{-1}\right)$. No hubo mayores diferencias entre las plantas fertilizadas con el abono orgánico y aquellos que han recibido un abono mineral equilibrado en cationes. La fertilización mineral desequilibrada en cationes no tuvo efecto en el crecimiento y la producción de las plantas de tomate en relación al tratamiento testigo sin abono. Conclusión. La aplicación de estiércol de ave en dosis adaptadas y en el buen momento permite mantener una producción de tomates equivalente a la que se obtiene con un abono mineral bien dosificado en los andosoles tropicales, pobres en potasio y en fósforo, y que presentan un exceso de magnesio.

Camerún / Solanum lycopersicum / frutas / andosoles / aplicación de abonos / abonos inorgánicos / abonos orgánicos / crecimiento / calidad 